\title{
Nurali Ophiolite Massif (the Southern Urals): Geological, Structural, and Mineralogical Features
}

\author{
D.E. Saveliev ${ }^{a}$, N.N. Ankushevab \\ ${ }^{\text {a }}$ Institute of Geology, Ufa Federal Research Center, Russian Academy of Sciences, 16/2 \\ Karl Marks Str., Ufa 450077, Russia. E-mail: savl71@ @ail.ru \\ ${ }^{\mathrm{b}}$ South Urals State University, Miass Department, Miass 456300, Russia \\ E-mail: ankusheva@mail.ru
}

(Paper accepted February 1, 2018)

An overview of a geological structure of Nurali massif is presented. Compositional data of ultramafic rocks from mantle section and transitional mantle-crust assemblages, and chemistry of accessory and ore-forming $\mathrm{Cr}$ spinels are examined. We showed that ultramafic rocks from mantle section (spinel a spinel-plagioclase peridotites, harzburgites, dunites) are the tectonites. They have a strong predominantly optical orientation of rock-forming olivine due to a plastic flow of rocks. We presented different points of view on the mantle-crust assemblage origin, which composed by wehrlites, clinopyroxenites, vebsterites, dunites and melanocratic gneiss-like gabbro, and described two PGE-occurrences in the chromitites of this ophiolite section unit. This paper is based on a guidebook of an International field trip to Nurali massif as a part of conference "Magmatism of the Earth and related deposits of strategic metals" held in 2017 August.

Key words: ophiolite; ultramafic rocks; Cr spinels; PGE-minerals; Southern Urals; Nurali.

DOI: 10.17072/psu.geol.17.3.228

\section{Historical outline}

The Nurali massif has been studied since the second half of the XIX century, after the first $\mathrm{Cr}$ ore mineralization discovery at the massif area. Prior to 1939, the extensive prospecting and exploration works have been carried out resulting in the discovery of more than $30 \mathrm{Cr}$ deposits and ore mineralization occurrences. The largest of them are Mokraya Yama and Attestinskiy ore occurrences located at the northern part of the massif and described in reports of P.G. Farafont'ev, I.M. Parfenov, and S.A. Konyukhov.

The systematic exploration of the area structure was started by V.S. KoptevDvornikov in 1932. Later, the massif was studied by the multi-scale geological (Muravyova, 1947; Sadrislamov, 1960; Anisimov, 1983) and complex geophysical survey (Vulfovich, 1963; Chursin, 1979). Time to time, the researche studies were carried out at the

(C) Saveliev D.E., Ankusheva N.N., 2018 massif (Poirier, 1985; Prokin, 1962; Edelstein, 1964; Cherkasov, 1973). In 19781980 , in result of the prospecting works for $\mathrm{Cr}$ bearing ores, the Nuralinskiy and Kurmankulskiy deposits were discovered (Shumikchin, 1980).

The detailed structural and petrological study of the ultramafic rocks of the Nurali massif was perfomed in $1980^{\text {th }}$ by G.N. Savelieva, E.A. Denisova, the scientists from the Geological Institute. They compiled the structural and geological map of the mantle ultramafic rocks and transition wehrlitepyroxenite unit, which characterizes the chemical composition of the rock-forming minerals, and provides the new approach for interpretation of the origin of the massif as one of the typical example of the lherzolitetype ophiolite complexes at the Southern Urals (Savelieva, Denisova, 1983; Savelieva, 1987). The nature of the transition dunitewehrlite-clinopyroxenite complex of the massif was studied in (Pertsev, Savelieva, 
1997; Pertsev et al., 1997; Kovalev et al., 1998).

In 1980th E. A. Shumikhin and T. A. Melnik started the investigation of the chromitites for Pt potential. These studies were continued by numerous Russian and foreign scientists (Dmitrenko et al., 1992; Grieco et al., 2007; Malitch et al., 2016; Moloshag, Smirnov, 1996; Saveliev et al., 2017; Smirnov, 1995; Smirnov, Volchenko, 1991; Zaccarini et al., 2004; Znamensky et al., 1996). PGM were found out at several $\mathrm{Cr}$ mineralizations: Priozernyy, Zapadno-Sherambayskiy, Mokraya Yama, Nuralinskiy.
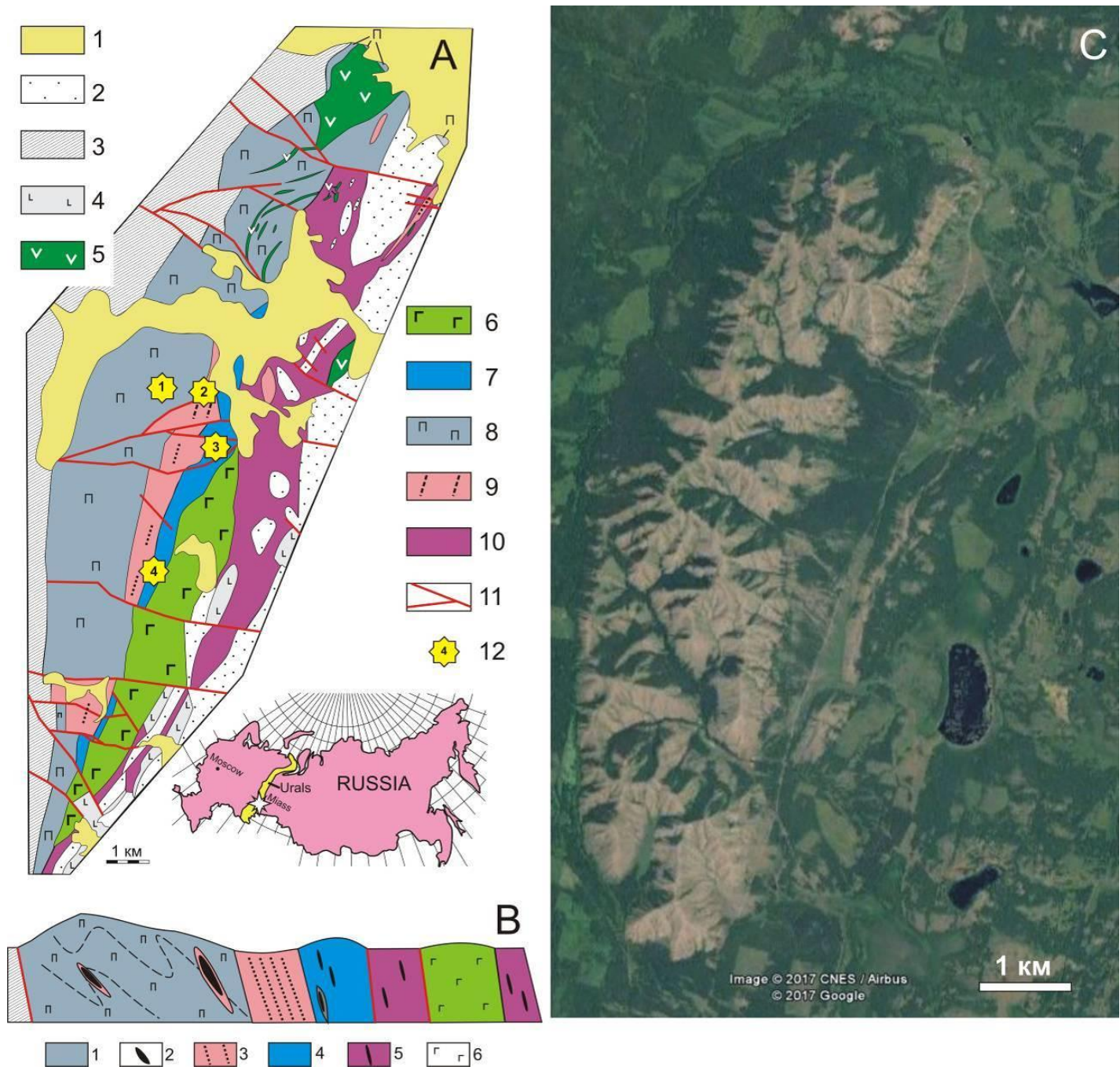

Fig. 1. Geological scheme of Nurali massif (modified from Shumikhin, 1980) (A), generalized crosssection of the massif $(B)$ and Google-map picture of the massif area $(C) . A-1$ - Quaternary alluvial and lake sediments, 2 - Paleozoic sedimentary rocks of the Western-Magnitogorsk zone, 3 -Precambrian sedimentary and metamorphic rocks of Uraltau, 4 - volcanogenic rocks of the WesternMagnitogorsk zone, 5 - subvolcanic gabbro and diabase bodies, 6-10-Nurali ophiolite complex, including: 6 - gabbroids, 7 - wehrlites and clinopyroxenites, 8 - spinel and spinel-plagioclase peridotites, 9 -dunites, 10 -serpentinites; 11 -cross-section faults, 12 -detail studied areas. B: 1 - plastic flowing peridotites, 2 - chromitites, 3 -dunites with low-disseminated chromitites, 4 - wehrlitepyroxenite complex, 5 - serpentinite mélange, 6 - gabbro

\section{General geological characteristics of the massif}

The Nurali massif is situated at the NE part of the Uchaly region in Bashkortostan Republic, near the Chelyabinsk region bor- der. The western part of the massif (Bolshoy Nurali Mountain) is a billowy area where the mountain slopes formed a variety of the small ridges interrupted with deep ravines (Fig. 1-3). A maximal altitude is of $754.2 \mathrm{~m}$, 
the relative elevations ranges from 250 to $300 \mathrm{~m}$, and the slope angles are $25-40^{\circ}$.
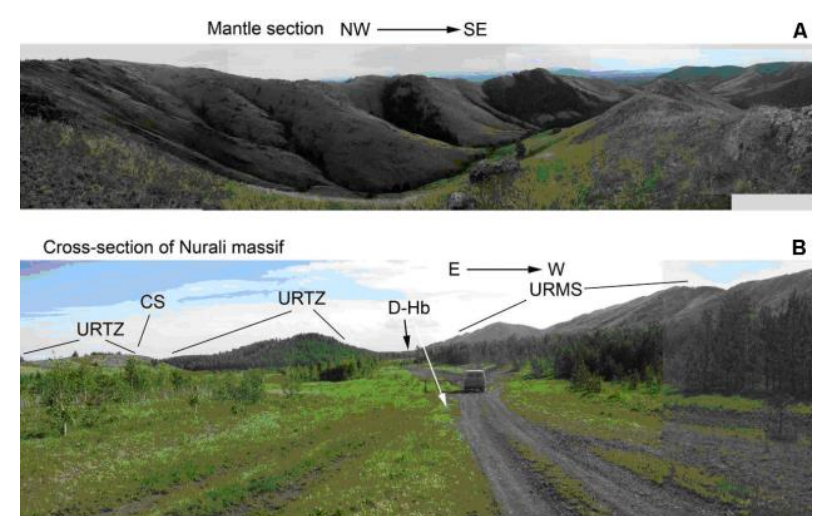

Fig. 2. Panoramic views of Nurali massif. $A-$ spinel-plagioclase and spinel peridotite outcrops at the central part of Nurali massif, Upper Miass river basin; $B-E-W$ section of the massif: $C S-$ crustal section (gabbro, basalts), URTZ - ultramafic rocks of the transition zone (wehrlites, clinopyroxenites), $\mathrm{D}-\mathrm{Hb}$-dunites and harzburgites, URMS - ultramafic rocks of the mantle section (spinel-and spinel-plagioclase peridotites)

To the East, the parallel ridge Maly Nurali is built with ultramafic rocks as well. Further, to the east it is followed by a hilly plane with polymictic mélange of blocks of the Paleozoic gabbroid, volcanogenic and volcanogenic-sedimentary rocks.

The ultramafic rocks are exposed at the area of about $120 \mathrm{~km}^{2}$ which is of $30 \mathrm{~km}$ long and $4-5 \mathrm{~km}$ wide. They are confined to the Main Uralian Fault zone bordering the paleocontinental (at the west) and paleooceanic (at the east) parts of the Southern Urals. The massif is split into the blocks with the latitudinal faults. The largest faults are associated with Nizhniy and Verkhniy Eremel, Sherambay, and Shardatma River valleys. The riverhead of the Miass River is located within the massif as well.

According to the geophysical data, the massif is close to an inverted cone in shape. Along its borders at the east and west parts, significant linear positive magnetic anomalies with strong centripetal reduction of the rock magnetic susceptibility were observed. Above the central part of the massif, the intensive positive gravity anomaly was record- ed that showed the significant extent of the serpentinized ultramafic rocks to the great depth (Rudnik, 1965).

As the majority of the ophiolite complexes, Nurali massif can be subdivided to the two assemblages: mantle unit occupies its western part and crustal unit is located at the eastern part. At the western part of the massif, spinel-plagioclase peridotites prevailed and followed by spinel peridotites and dunite-harzburgites forming a narrow belt at the East along the border of the "crustal section" (Fig. 1).

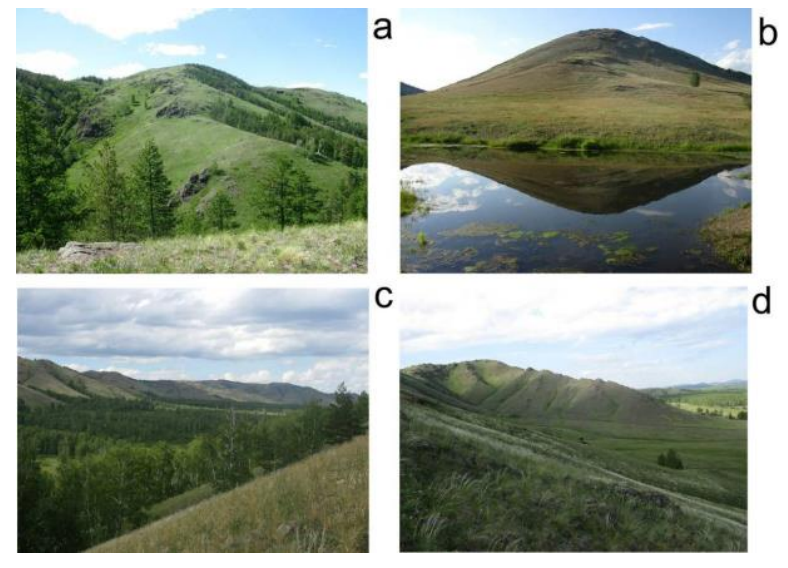

Fig. 3. The overviews of Nurali massif: $a$-typical landscape of the mantle complex area, $b$ - the same, the pond at the upper Miass River basin, $c$ - the view from Malyy Nuraly Ridge slope to Bolshoy Nurali Ridge: left - mantle peridotites therein a low area at the centre - duniteharzburgite complex, the shooting point is marked ultramafic rocks of the transition wehrlite-clinopyroxenite complex, $d$ - the extensions of Bolshoy Nurali Ridge at the southern part of the massif

The largest area is occupied by alternated spinel and prevalent spinel-plagioclase peridotites. Their structures are characterized by elongated schlieren consisted of fully saussuritized plagioclase and skeletal $\mathrm{Cr}$ spinel grains. Harzburgites differs from them by absence of clinopyroxene and plagioclase, higher $\mathrm{Mg \#}$ of olivine, and orthopyroxene, which constitute 70-90\% and $10-30 \%$ of bulk rock, correspondingly. The average rock chemical composition is summarized in Table 1.

The banding of harzburgites is more expressed and caused by irregular distribution 
of the enstatite. The flattened enstatite grains conform to a banding of NE strike and subvertical dip. All of peridotite species contain Cr-spinels (1-5 \%). Their aluminous species are related to spinel peridotites. Harzburgites contain more the $\mathrm{Cr} \#$ of accessory $\mathrm{Cr}$-spinel, which is subhedral and shine with reddishorange colors.

Dunites contain olivine (95-98\%) and Cr-spinel (до $5 \%$ ). The oriented structures are characterized by elongated olivine grains and $\mathrm{Cr}$-spinel chains. As a rule, they conform to each other and dunite-harzburgite banding at NE strike and subvertical dip. Olivine is rock-forming mineral and contains $8-9 \%$ of fayalite. Cr-spinel is high-chromium and redbrown shine.

The main features of dunite-harzburgitelherzolite part of the massif are following: 1) the general development of the deformed structures indicated high-temperature plastic deformation of rocks, 2) the gradual increase of $\mathrm{Mg \#}$ concentration from the west to east toward the contact with banding dunitewehrlite-pyroxenite complex.

The eastern part of the Nurali massif consists of wehrlite-pyroxenites and gabbroids. The ultramafic sequence includes websterites, orthopyroxenites, plagioclase pyroxenites, hornblendites, and cumulose harzburgites, and dunites (Kovalev et al., 1998; Pertsev, Savelieva, 1997; Smirnov, 1995). The presence of the stratiform ultramafic zone is an important peculiarity. The bands are from $0.5 \mathrm{~cm}$ to several meters thick, and "layers" reach the hundred meters in thickness. Clinopyroxenites and wehrlites prevail in stratiform zone, but essentially olivine bands are rare. This zone is $30-50 \mathrm{~m}$ thick with subvertical and steep western dip. Along with the banding, we observed a concordant flatness of olivine grains or sometimes lath-like aggregates. Wehrlites and clinopyroxenites are characterized by porphyroclastic structures.

East ultramafic rocks of duniteharzburgite-pyroxenite complex followed by gabbroids composing low areas near the $\mathrm{Nu}$ rali Lake. Their bedrock is alternated with the outcrops and eluvium of serpentinites and volcanogenic-sedimentary rocks. Gabbro forms isolated block within serpentinite mélange and is represented by medium- and coarse-grained gabbro-diorites, banded hornblendite, fine-grained gabbro, and gabbroamphibolites.

\section{Mineral resources of the Nurali massif}

The Nurali massif includes numerous small deposits and $\mathrm{Cr}$ ore mineralizations. The most of them form lense and podiform ore bodies composed by massive and closedisseminated chromitites hosted in fully serpentinized ultramafic rocks. As a rule, prevalent apoperidotite serpentinites and $\mathrm{Cr}$ ores are separated by a thin apodunite serpentinite rim that is a typical peculiarity of ophiolite (Alpine-type) Cr deposits.

The Mokraya Yama is the largest deposit at the massif. According the archived data, in 1902 it produced more than $150000 \mathrm{t}$ of massive and close-disseminated chromitites (Kovalev, Salikhov, 2000). The quarry is currently remained and submerged. The destroyed bank consists of fully serpentinized ultramafic rocks. At the quarry flanges, apodunite and apoharzburgite serpentinites prevail, and an adjacent area is composed mainly by apoharzburgite serpentinites.

South from the Mokraya Yama deposit, the chain of small ore mineralizations of the Olgino ore cluster is situated with the largest Siyak-Tukan deposit and Petrovskiy quarry. They have been fully studied until now. Likewise, ore bodies of the Mokraya Yama deposit, which ore mineralization is lens-like, are composed of massive chromitites with thin apodunite serpentinite rims.

In addition to typical Alpine-type chromitites, several submeridional zones consisting of disseminated chromitites are located at the eastern part of the massif. They are confined with so called "margin dunites" separated spinel- and spinel-plagioclase peridotites from wehrlite-clinopyroxenitegabbro complex. The Nurali is the largest this type deposit. Attestinskiy and Kurmankulskiy deposits are situated and at the northern part of this dunite zone. According to the morphological classification (Cassard et al., 1981), these deposits conform 
to tabular bodies concordant to the hosted ultramafic rocks.

The small chromitite mineralization is located in wehrlite-clinopyroxenite complex (Priozernyy (South Miass, CHR-II)) and Zapadno-Sherambayskiy (Kn-192, CHR-I)) with higher PGE contents.

\section{The compositions of accessory and ore-forming Cr-spinels}

The Cr-spinels of the Nurali massif contain significant variations of the main components $(\mathrm{Cr}, \mathrm{Al}$, and $\mathrm{Fe})$ and can be subdivided into several groups: 1) accessory spinels of peridotites, 2) ore-forming spinels of $\mathrm{Cr}$ deposits in dunites and apodunite serpentinites, 3) accessory and ore-forming spinels of wehrlite-pyroxenite complex (Table 2, Fig. 4).

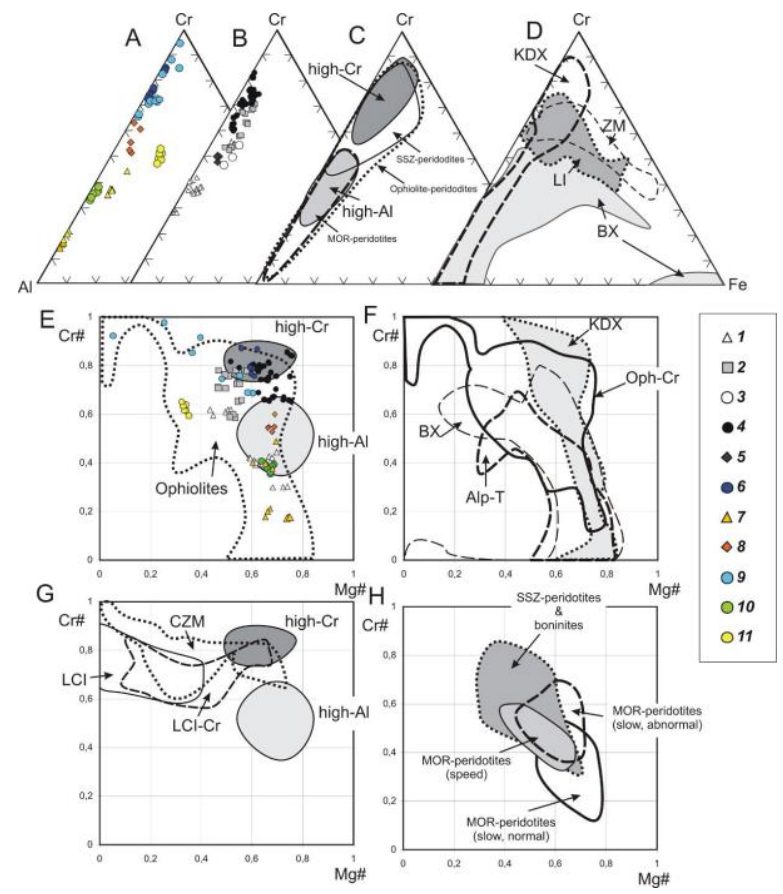

Fig. 4. The chemical compositions of $\mathrm{Cr}$ spinels plotted in $\mathrm{Al}-\mathrm{Cr}-\mathrm{Fe}^{+3}$ and $\mathrm{Mg \#}-\mathrm{Cr} \#$ diagrams (c.f.). $A-B-A l-C r-F e^{+3}$ (c.f.) diagram for $\mathrm{Cr}$ spinels of Nurali massif: A - after (Saveliev et al., 2017), B - data of G.G. Dmitrenko (unpublished data), $C-D$ - triangle diagrams of compositions of Cr-spinels from different formational ultramafic rocks; $E-H$ - binary $M g \#-C r \#$ diagrams for Cr-spinels of Nurali massif $(E)$ and different formational ultramafic rocks $(F-H) .1-$ peridotites, 2 -dunites, 3 -wehrlites and clinopyroxenites, 4 -chromitites from the small dunite lenses in peridotites, 5 - chromitites from a huge dunite horizon, 6 - peridotites, 7-11 - oreforming Cr-spinels, including: 7 - middlechromous in peridotites and serpentinites, 8 high-chromous in dunites, 9 - high-chromous in massive bodies, 10 - Priozerny ore mineralization, 11 - Zapadno-Sherambaysky ore mineralization. $C-D$ - different formational ultramafic rocks from various geotectonic envinronments. Abbreviations: high-Cr - high-chromous oreforming Cr-spinels from ophiolites, high-Al high-aluminous ore-forming Cr-spinels from ophiolites, SSZ - supra-subductional peridotites (and boninites), BX - ultramafic xenoliths in basalts, KDX - ultramafic xenoliths in kimberlites, LCI - chromite-bearing stratified intrusions, ZCM - concentric-zonal massifs. Fields are after (Barnes, Roeder, 2001; Saveliev et al., 2008)
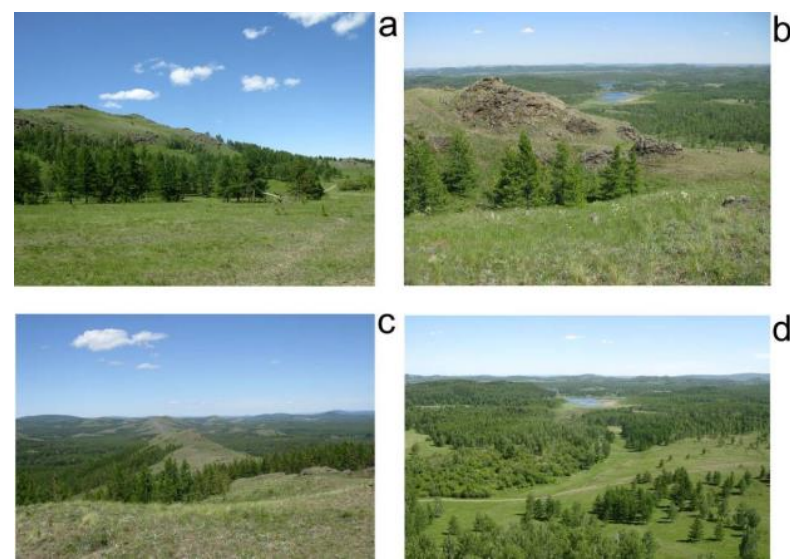

Fig. 5. Mantle section ultramafic outcrops and overviews: $a, b$-spinel peridotite outcrops at the crest extension of Bolshoy Nurali Ridge, $c$ - the view to the north from the crest extension, $d$ - the view to the east from the crest extension (Sherambay Lake)

The accessory spinels in peridotites of lherzolite-harzburgite sequence are represented by chromepicotites characterized by an absence of $\mathrm{Fe}^{3+}$ and significant modification of $\mathrm{Cr} /(\mathrm{Cr}+\mathrm{Al})$ ratio. They have the aluminous composition ( $\mathrm{Cr} \#$ 0.17-0.6) and higher Mg\# (0.6-0.8). The strong elevation of $\mathrm{Al}$ in minerals is noted as in the central parts of peridotite sequence as in the eastern part in the transition zone to dunites. The contents of the main components are (wt. \%): $\mathrm{Cr}_{2} \mathrm{O}_{3}$ 16-38, $\mathrm{Al}_{2} \mathrm{O}_{3}$ 26-53, $\mathrm{MgO}$ 13-19, $\mathrm{FeO}$ 11-20. The admixture elements are $\mathrm{MnO}$ (до $0.19 \%$ ), $\mathrm{NiO}$ (до $0.28 \%$ ) and $\mathrm{TiO}_{2}$ (до $0.15 \%$ ). The most typical for the acces- 
sory $\mathrm{Cr}$ spinels are the anhedral aggregates associated with plagioclase.
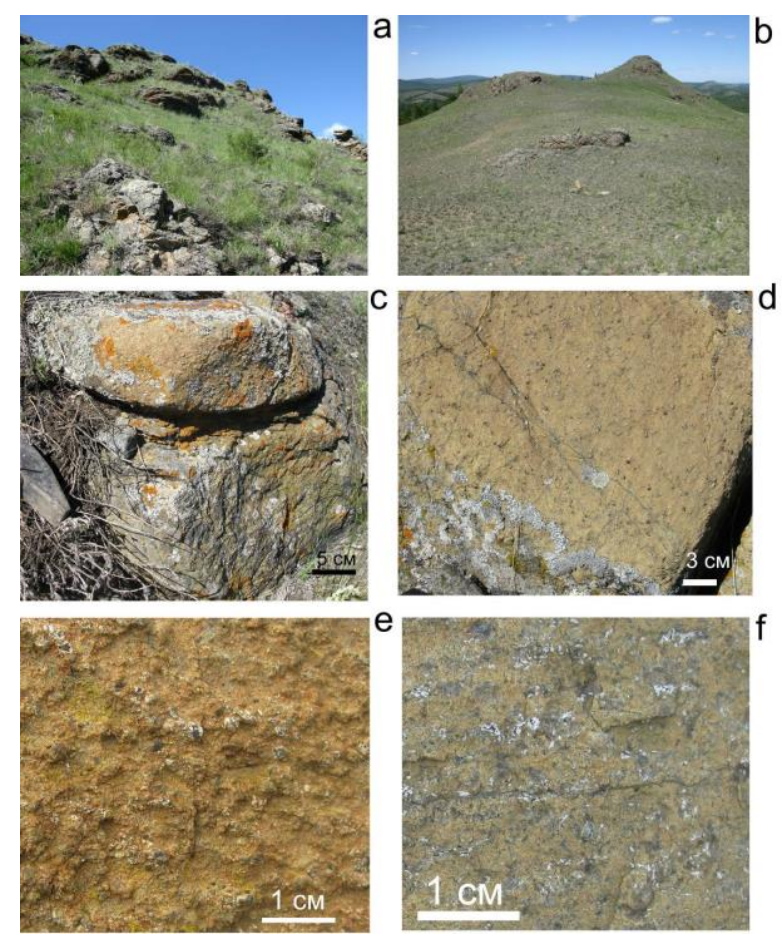

Fig. 6. Multi-scale mantle ultramafic outcrops

The ore-forming spinels have higher $\mathrm{Cr} \#$ (0.6-0.9) compared with accessory minerals of peridotites. Same time, they can be subdivided into two subtypes similar to those in numerous ophiolite complexes. Mostly they are the ore mineralizations and deposits composed of high-chromous spinels alumochromites (Mokraya Yama, SiyakTukan, Attestinskiy, Kurmankulskiy, and Nuralinskiy). The contents of the main components are (wt. \%): $\mathrm{Cr}_{2} \mathrm{O}_{3} 54-65, \mathrm{Al}_{2} \mathrm{O}_{3} 6-$ 13, $\mathrm{MgO} 7-12, \mathrm{FeO} 13-25$. The admixture elements are $\mathrm{MnO}$ (up to $0.3 \%$ ), $\mathrm{NiO}$ (up to $0.07 \%$ ) and $\mathrm{TiO}_{2}$ (up to $0.15 \%$ ). The strong content increase of $\mathrm{MnO}$ (up to $1 \%$ ) and $\mathrm{NiO}$ (up to $0.65 \%$ ) is observed in metamorphosed parts of grains.

The morphology of ore-forming $\mathrm{Cr}$ spinels is described as follows: small rounded euhedral grains in disseminated ores; and strongly fractured anhedral grains in massive ores. Middle-chromous spinels (Cr-picotite) are exposed at the Sredne-Nuralinskiy ore mineralization located within peridotites at the central part of the massif, and serpentinite mélange at the eastern part of the massif. The contents of the main components are (wt. \%):
$\mathrm{Cr}_{2} \mathrm{O}_{3}$ 41-47, $\mathrm{Al}_{2} \mathrm{O}_{3}$ 20-23, $\mathrm{MgO}$ 13-15, $\mathrm{FeO}$ 15-18. The admixture elements are $\mathrm{MnO}$ (up to $0.1 \%$ ), $\mathrm{NiO}$ (up to $0.15 \%$ ) and $\mathrm{TiO}_{2}$ (up to $0.24 \%$ ).

\section{Framework of detailed areas}

\section{The mantle section of the massif}

Upper mantle section of Nurali ophiolite is presented most completely in the northern part (see Fig. 1, outcrop 1). Here, the slope and crest of Nurali Ridge are composed of spinel peridotites with variable contents of ortho- (10-25\%) and clinopyroxenes (0$10 \%$ ) (Fig. 5). The rocks contain serpentinized olivine (70-90\%). Cr-spinel is an accessory mineral (0.n-2\%).

Most of peridotites are strongly fractured that prevents to observe the orientation of the main structural elements. 'Fresh' rocks are rare. We observed orthopyroxene grains (yellowish-green enstatite), clinopyroxene (lightgreen diopside) and Cr-spinel (Fig. 6). In the olivine groundmass, "negative" micro relief is revealed. Monomineral olivine parts are characterized by a smooth homogeneous light-brown surface.

The differences between the amounts of pyroxenes and olivine in groundmass specified the banding, which is an important structural element of peridotites. The orientation of pyroxene grains and $\mathrm{Cr}$-spinels indicate the mineral foliation and lineation. During the study of peridotites with an optical microscope, we observed the rock microstructure and measured the orientation of olivine grains. According to the measurements, we determined a statistical position of structural rock elements to map the special symbols.

On the west part of Nurali Ridge, spinel peridotites prevail (lherzolites and clinopyroxene-containing harzburgites), but toward the watershead ridge area, spinel-plagioclase peridotites are growing. The ratios between pyroxenes, olivine, and $\mathrm{Cr}$-spinels are the same, but plagioclase is always occurs associated with Cr-spinel (up to $10 \%$ ). Typically, the schlieren-shaped aggregates composed of the anhedral to dendritic $\mathrm{Cr}$-spinel exposed usually at the central parts, and plagioclase rim are observed (Fig. 7). 

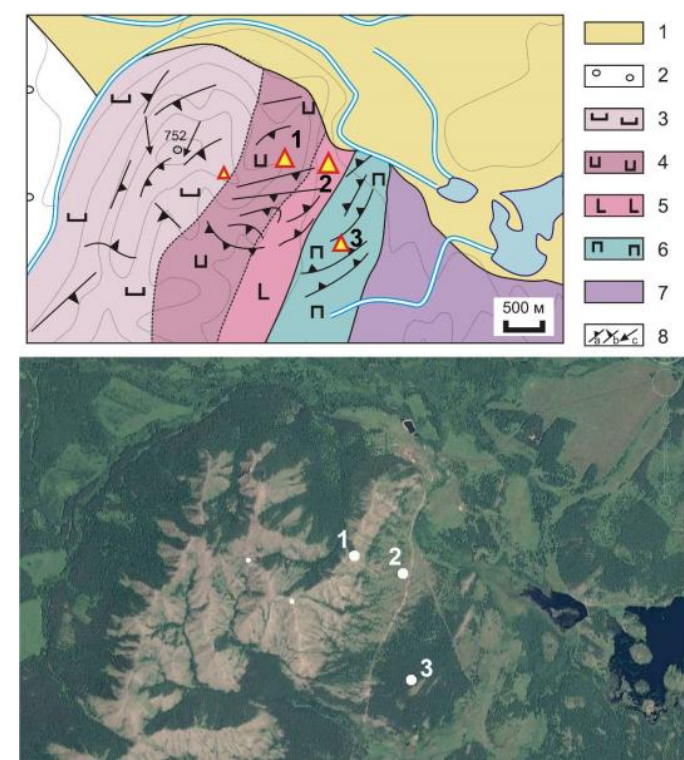

Fig. 7. The structural and geological map of the fragment of Nurali massif northern part (outcrops 1-3) (Savelieva, Denisova, 1983). 1 - Quaternary alluvial and lake sediments, 2 - Precambrian and Early Paleozoic sedimentary rocks, 3 5 - mantle section of ultramafic rocks: 3 - predominantly spinel-plagioclase peridotites, 4 spinel peridotites, 5 -dunites and harzburgites, 6 - wehrlite-clinopyroxenite transition complex, 7 - serpentinite mélange, 8 - structural elements, $a$ - foliation ( $\left.\angle 40-90^{\circ}\right), b-$ foliation ( $\angle 0-40^{\circ}$ ), $c$ - lineation. Transmitted light. Left - crossed nicols, right-parallel nicols; right and left photos are of the same scale $0.1 \mathrm{~mm}$

On Fig. 7 we can see the mantle section structure of the latitudinal area of our route described in (Savelieva, Denisova, 1983; Denisova, 1990). At the scheme and outcrops, we observed the banding, flatness, and lineation. Although, we did not observe any clear structural elements in lumps and outcrops, but, if interpolate the large number of data, we can examine a folded structure of the mantle section of the massif.

Studying the peridotites with an optical microscope, we observed numerous indicators of high-temperature plastic deformation of the main rock-forming olivine and orthopyroxene (Fig. 8-10). These minerals react to the expended stress in different ways. Olivine forms fragments of grains (polygonization) with developed substructures, and significantly elongated grains divided into blocks with small-angle borders.
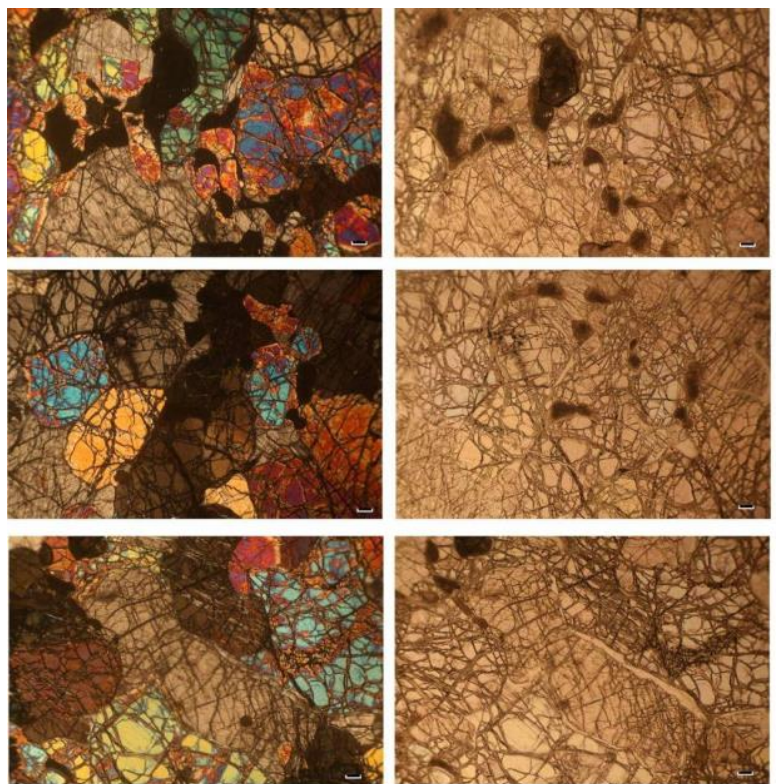

Fig. 8. Petrographical peculiarities of spinelplagioclase peridotites

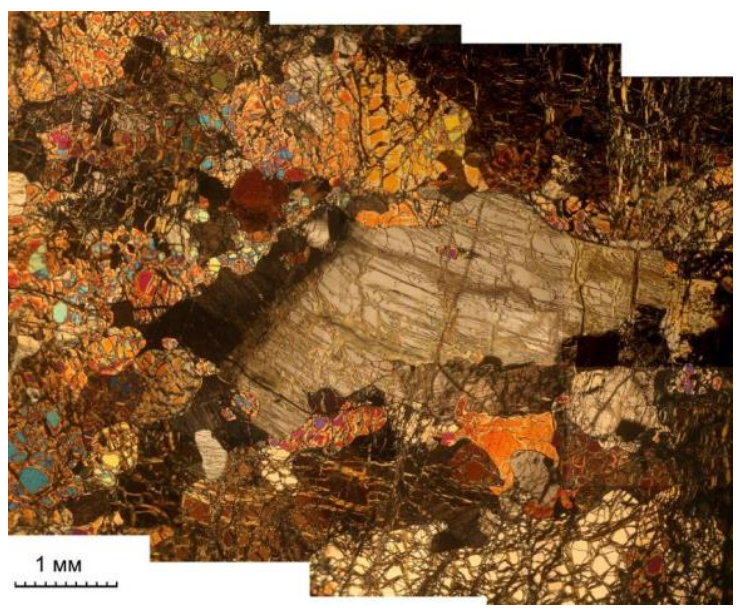

Fig. 9. Deformed structure of peridotite. Transmitted light, crossed nicols. At the center-large deformed orthopyroxene crystal in olivine groundmass divided into differently oriented blocks

Occasionally, a disorientation is revealed within large grains that indicated by the presence of small olivine inclusions in the same groundmass. These events are caused by the intragranular or rotary recrystallization (Carter, 1976; Poirier, 1985).

On the contrary, an orthopyroxene is characterized by the adversely oriented grains bend to form kink-bands (Fig. 9), an intensive nucleation that means the formation of numerous centers of recrystallization at the points with the most distorted crystal lat- 
tice, and the formation of clinoenstatite and diopside lamella inside the bended grains.
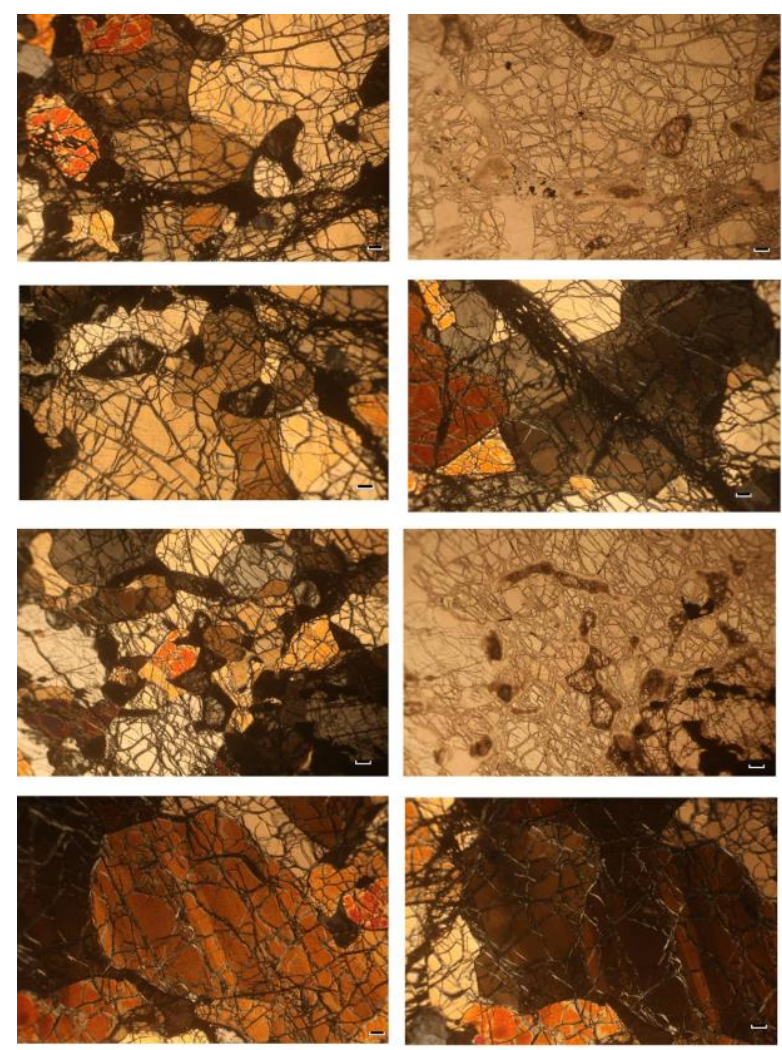

Fig. 10. Petrographical peculiarities of spinelplagioclase and spinel peridotites. Transmitted light. $a-b, e-f-$ the same areas: left - crossed nicols, right - parallel nicols; $c$ - small twinned plagioclase therein olivine groundmass (crossed nicols), $d, g, h$ - plastically deformed olivine crystals with fault lines (crossed nicols). A scale is $0.1 \mathrm{~mm}$

The polished sections were studied using an universal stage (Fedorov's stage) to reveal the preferred orientation of the main crystallographic sides of olivine and orthopyroxene (Savelieva, Denisova, 1983). Regarding the structural rock elements, enstatite crystals are conformed to the translational sliding along (100) [001] (Fig. 11). In olivine, two fabric patterns were observed. The first of them is similar to the translational sliding along (010) [001] with a partial [100] peak. The second one has peaks of lineation at a small angle to $\mathrm{Nm}$, and conform to the sliding of slip system (010)[001] and recrystallization (Fig. 12). Thus, micro- and petro structural data indicate that spinel- and spinel-plagioclase peridotites of this section are mantle tectonites formed due to plastic flowing at high temperature and pressure.

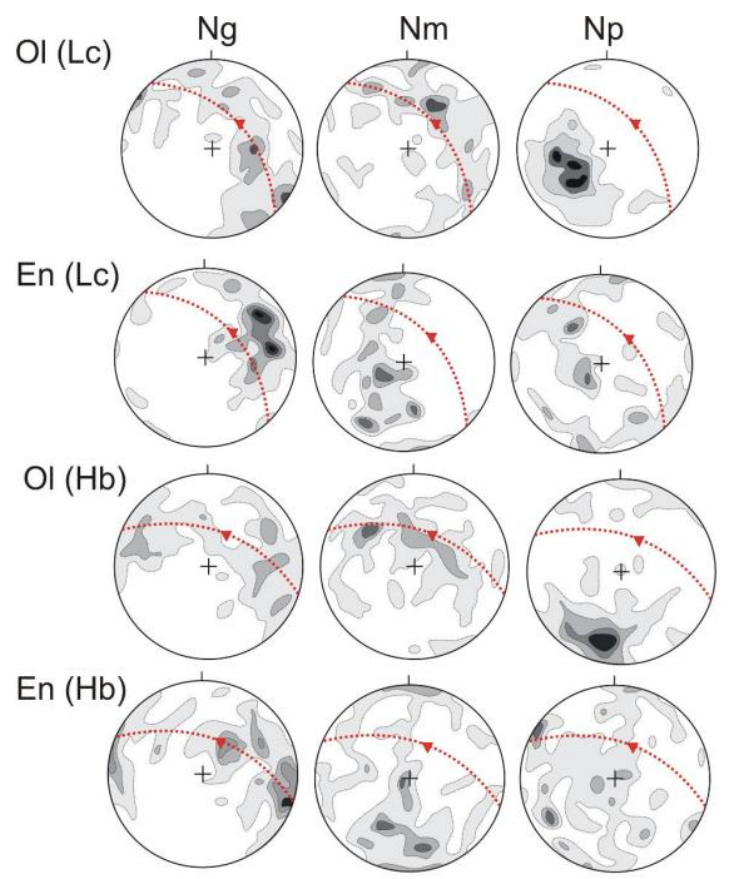

Fig. 11. Petrostructures of olivine and orthopyroxene from peridotites of Nurali massif (Savelieva, Denisova, 1983). The upper semi-sphere of equal square projection, isolines 1-3-5-7-9\%. Solid lines - mineral flatness and banding, triangles - lineation; $a$, $b$-spinel-plagioclase peridotite, $c, d$-harzburgite; $a-150$ grains, $b-$ 105 grains, $c-160$ grains, $d-86$ grains

Dunites and dunite-harzburgites formed poorly exposed low area located between the mantle and crustal sections at the Nurali massif (see Fig. 2). Usually we observed eluvial dunite debris, and rarely, flat outcrops along the gravel road.

Dunites are almost monomineral rocks composed of olivine (95-98\%), accessory Cr-spinel crystals (0.n \%) and sparse pyroxene grains $(<1 \%$, diopside and enstatite). In transition dunite-harzburgites, enstatite content is increased to up to 5-10\%. Dunites and dunite-harzburgites have light-brown weathering incrustation and smooth surface (Fig. 13). We observed isolated Cr-spinel grains and strias forming the main conformed macro texture of rocks (see Fig. 13). Generally, chromite strias are conformed to the contacts between dunite-harzburgite and both mantle section peridotites, and wehrliteclinopyroxenite of transition complex. 

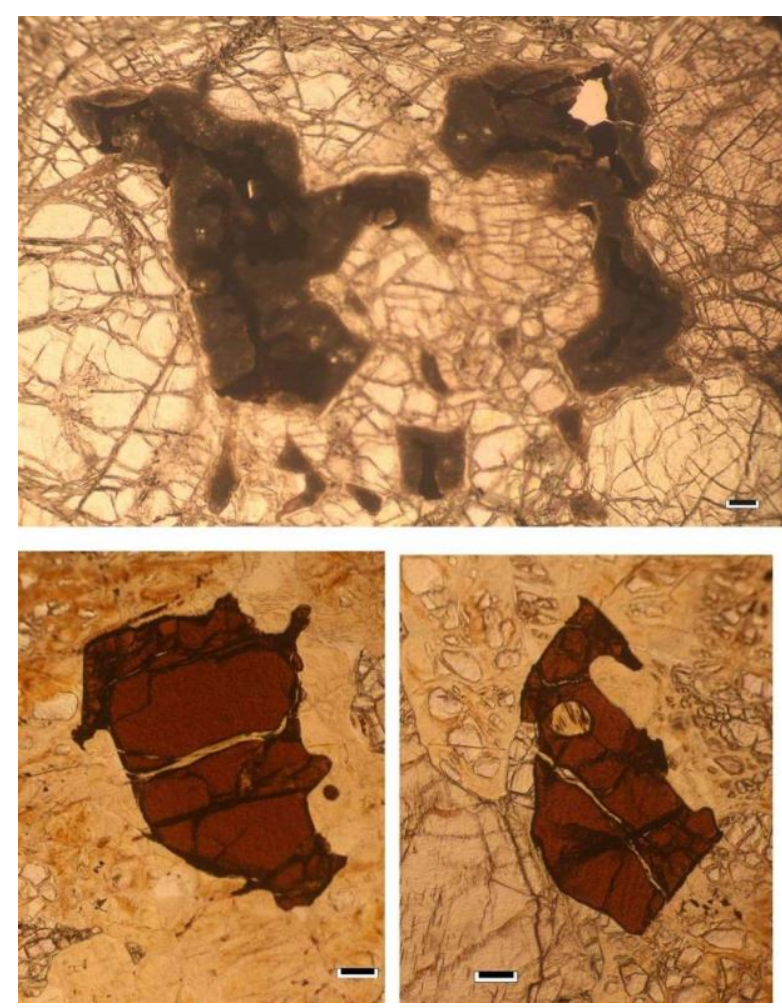

Fig. 12. Typical Cr-spinels grains associated with pelitizated plagioclase in spinel-plagioclase (a) and spinel peridotites (b, $c$ ). Plate-polarized light, parallel nicols; a scale is $0.1 \mathrm{~mm}$

Microscopically, olivine in dunites indicates the high-temperature translational sliding, and frequently we observed the plastic fracture bands and subgrain borders (Fig. 14) expressed in heterogeneous grain extinction. Olivine grains are from micrometers to 3-5 $\mathrm{mm}$ in size that caused by an intensive polygonization and recrystallization of rocks in a plastic deformation envinronment. Olivine is highly magnesian and contain 90-92 $\%$ of a forsterite. Cr-spinel forms small grains $(0.0 \mathrm{n}-0.5 \mathrm{~mm})$, usually with a euhedral habit. They are highly chromous with $\mathrm{Cr}_{2} \mathrm{O}_{3}$ more than 50 wt. \% (Table 2). The primary olivine is altered and replaced mainly by a low-temperature loop-shaped serpentine preserved the primary rock structure. The extent of serpentinization ranges between 40 and $90 \%$.

Dunites and dunite-harzburgites compose Nurali poor impregnated $\mathrm{Cr}$ ore deposit discovered by E.A. Shumikhin in 1980 (Fig. 15). At Nurali deposit, up to $700 \mathrm{~m}$ long and 20-35 m thick 5 ore zones are revealed. These ore zones have NE strike $\left(50-60^{\circ}\right)$, and
NW dip (70-80 $0^{\circ}$, and conformed the banding of host rocks. Inside the zones, $130 \mathrm{~m}$ long and 2.5-12 m thick 4 ore bodies were explored. Ores are poorly impregnated with $\mathrm{Cr}$ content ranged between 5 and $30 \%$. The estimated $\mathrm{Cr}_{2} \mathrm{O}_{3}$ resources are 1.6 mil tons with average 5-7 wt.\%.

\section{The transition wehrlite-clinopyroxenite complex}

We consider the framework of this complex on two examples (see Fig. 1, outcrops 3 and 4). There is Zapadno-Sherambayskiy chromite ore mineralization inside the transition mantle-crustal complex. In addition to this name listed on the map compiled by E.A. Shumikhin [1980], other names are used in literature: "KN-192" (Smirnov, 1995) and "CHR-II" (Zaccarini et al., 2004). The rocks have lens-like and banded structures with different content of olivine and clinopyroxene. Furthermore, there are the areas enriched with orthopyroxene and Cr-spinels.

Olivine is intensively altered and replaced by serpentine veinlets with abundant powdered secondary magnetite. The latter indicates increase of Fe\# content in the primary olivine compared with that of mantle section peridotites. The section is composed by wehrlites and olivine clinopyroxenites. Websterites are rare.

Alternating wehrlites and websterites are unevenly enriched with $\mathrm{Cr}$-spinels with content from the first percentages up to almost monomineral chromitite veinlets and lenses of several millimeters to $1-2 \mathrm{~cm}$ thick conformed to a general banding of host rocks. According to S.V.Smirnov (1995), the chromitite formation is related to "apowehrlite high-temperature metasomatic websterites" with a persistent body thickness. They are conformed to the wehrlite jointing. Further, it was established that "metasomatic orthopyroxenes" are formed in wehrlites with content increase toward the contact with websterites (Smirnov, 1995).

Cr-spinels contain the elevated amounts of $\mathrm{Fe}, \mathrm{Ti}$, and $\mathrm{V}$ along with a lower $\mathrm{Mg}$ content. The chemical composition of $\mathrm{Cr}$-spinels 
is (wt. \%): $\mathrm{Cr}_{2} \mathrm{O}_{3} 36-41, \mathrm{Al}_{2} \mathrm{O}_{3}$ 14-17, $\mathrm{MgO}$ 6-8, $\mathrm{FeO}$ 36-38, corresponding to ferrialumochromite. Admixture elements are $\mathrm{TiO}_{2}(0.81-1.03 \%), \mathrm{V}_{2} \mathrm{O}_{5}(0.19-0.44 \%)$, and less $\mathrm{MnO}$ (up to $0.31 \%$ ). Ore grains are subhedral and $0.1-1 \mathrm{~mm}$ in size.

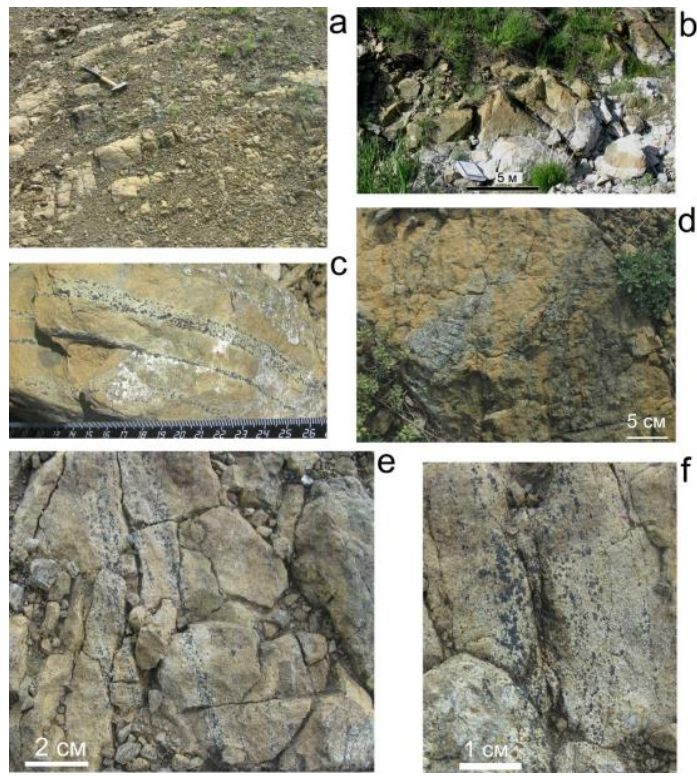

Fig. 13. Dunite and dunite-harzburgite outcrops: $a$-flat dunite and harzburgite outcrops near the road along the massif (outcrop 2), $b$-dunite outcrops at the wall of a mud hole at the Miass dry riverbed, $c$-banded impregnated chromitite in dunite (Nuralinskiy deposit), $d-$ duniteharzburgite outcrop, e-f - stria-banded chromitite in dunite (Nuralinskiy deposit)

Chromitite veinlets have the elevated PGE contents discovered in $1990^{\text {th }}$ by S.V.Smirnov and colleagues (Moloshag, Smirnov, 1996; Smirnov, 1995; etc.). The impregnated chromitites are confined to the zone composed of thinly alternated wehrlites, clinopyroxenites 6 and websterites. The ore zone is about $50 \mathrm{~m}$ wide and $5 \mathrm{~m}$ thick. According to Znamenskiy et al., 1996; Zaccarini et al., 2004; Grieco et al., 2007, mineralized ultramafic rocks and chromitites contain PGE up to 5-15 ppm. The following PGE minerals are revealed in chromitites: $\mathrm{Pt}-\mathrm{Pd}-\mathrm{Cu}$ intermetallides, native palladium $\mathrm{Pt}$, native ferriferous Pt, PGE sulfides (cooperite, lauriteerlichmanite), Pt-Pd-Fe-Cu-Ni alloys, potarite, Pt-Pd-containing awaruite and wairauite (Moloshag, Smirnov, 1996; Zaccarini et al., 2004; Saveliev et al., 2017). The nodules of magnetite, pyrrhotite and pentlandite, along with awaruite inclusions, contain tabular microinclusions of $\mathrm{Pt}-\mathrm{Cu}$ intermetallides of 1 $2 \mu \mathrm{m}$ in size. Furthermore, native $\mathrm{Cu}$ inclusions with admixtures of $\mathrm{Pt}$ and $\mathrm{Pd}$ are found in pentlandite.

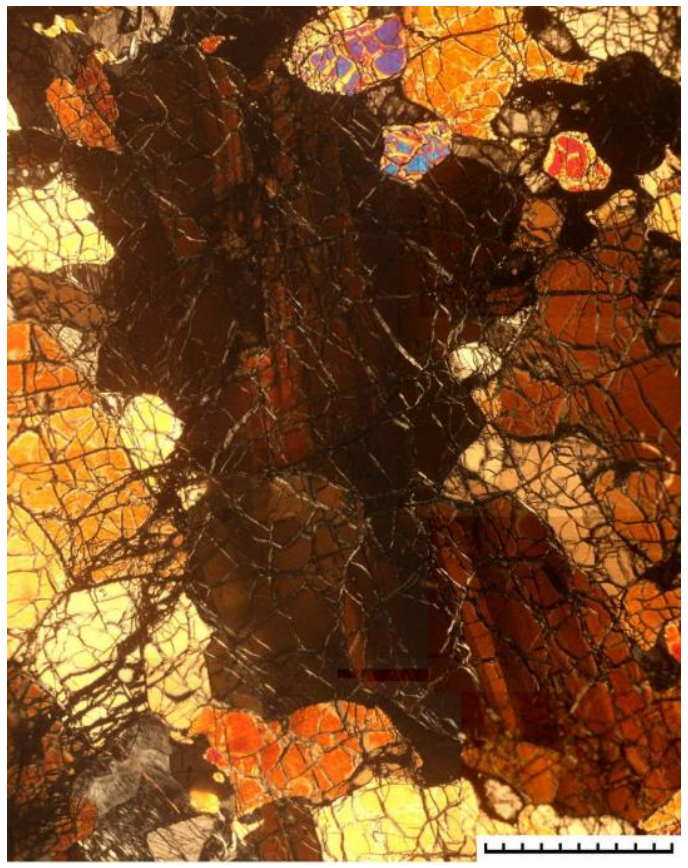

Fig. 14. Plasticaly deformed olivine in harzburgite of Nurali massif. Cross polarized translucent light. In large deformed olivine crystal, one can clearly observe the fault lines

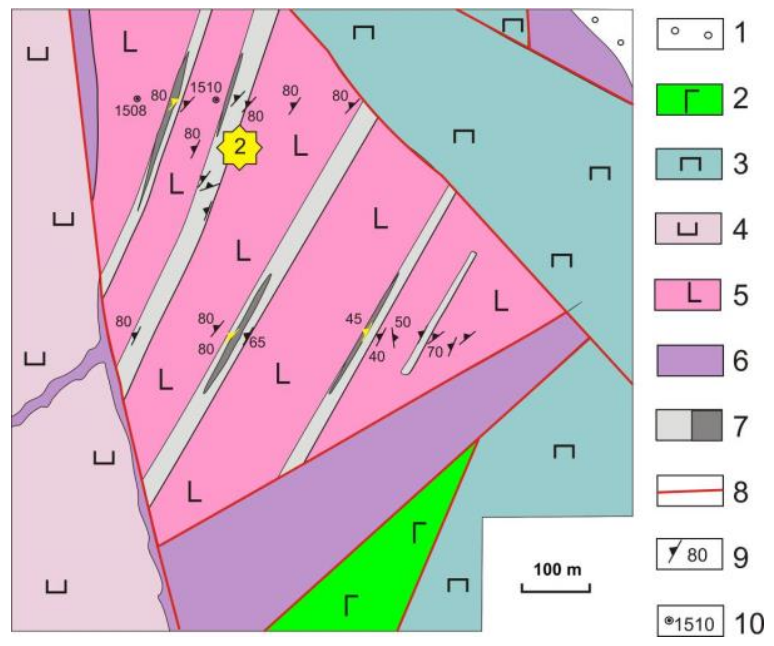

Fig. 15. Geological structure of Nuralinsky deposit, after E.A. Shumikhin [1980]: 1 - sedimentary rocks of Zilair Suit $\left(D_{3}-C_{1}\right), 2-$ gabbroids, 3 -wehrlites, clinopyroxenites, 4 - peridotites, 5 - dunites, 6 - serpentinites, 7 - mineralized zones and impregnated chromitite bodies, 8 faults, 9 - occurrence elements of Cr-spinel streaming, 10-holes 
The section of the transition wehrliteclinopyroxenite complex is in outcrop $4 a$ (Fig. 18). It was widely presented in many publications (Smirnov, 1995; Pertsev et al., 1997; Kovalev et al., 1998). Based on mentioned above, we listed the general description of the complex section. Petrographical peculiarities are shown in Fig. 19-21. The average rock-forming chemical composition is presented in Table 3 .

1) The fractionally alternated layers and lenses of clinopyroxenites, olivine clinopyroxenites and wehrlites are $1-10 \mathrm{~cm}$ thick. They have fine- and medium-grained structure, "fresh" clinopyroxene (diopside) and an intensive olivine serpentinization with rare olivine relics. Apoolivine serpentine is $\beta$ lizardite with abundant secondary magnetite grains. At the lower (eastern) part of this horizon, ore mineral is magnetite. Cr-spinel is identified at the upper part. Among the homogeneous section of the mainly fine-grained rocks, we observed the coarse-grained clinopyroxenite schlieren of 50-70 m thick.

2) The fractionally alternated olivine clinopyroxenites and wehrlites contain rare orthopyroxene grains, lenses of monomineral olivine rocks and clinopyroxenites, and thin layers and schlieren of websterites, and orthopyroxenites. The amount of clinopyroxenites increases to the top of the horizon, along with amphibole enrichment. Additionally, chromitite layers and lenses $3 \times 10 \mathrm{~m}$ in size are confined to this horizon of 100 $150 \mathrm{~m}$ thick (Priozernyy ore mineralization).

3) Olivine rocks with uneven (banded and lense-banded) enstatite varies to pegmatoid harzburgite contained long-prismatic enstatite (Pertsev, Savelieva, 1997). The thickness of this unit ranges from 1 to $3 \mathrm{~m}$.
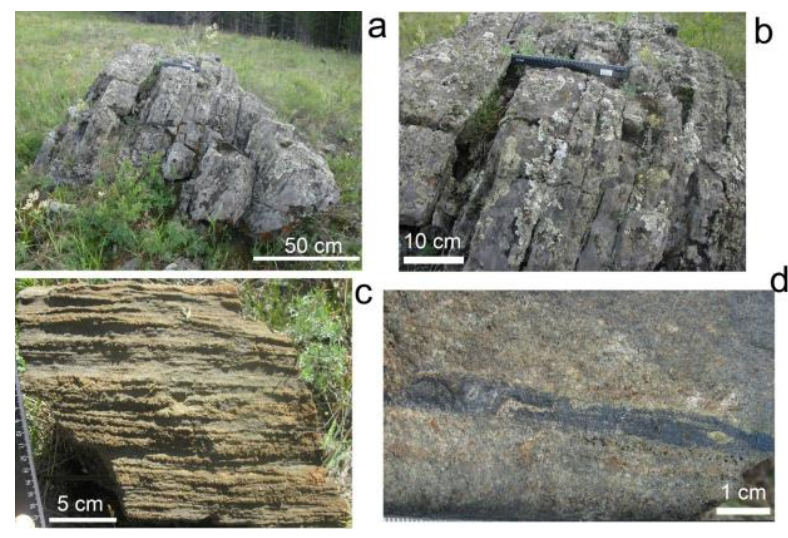

Fig. 16. The outcrops of ultramafic rocks related to wehrlite-clinopyroxenite at Zapadno-Sherambayskiy Pt-bearing chromitite exposure
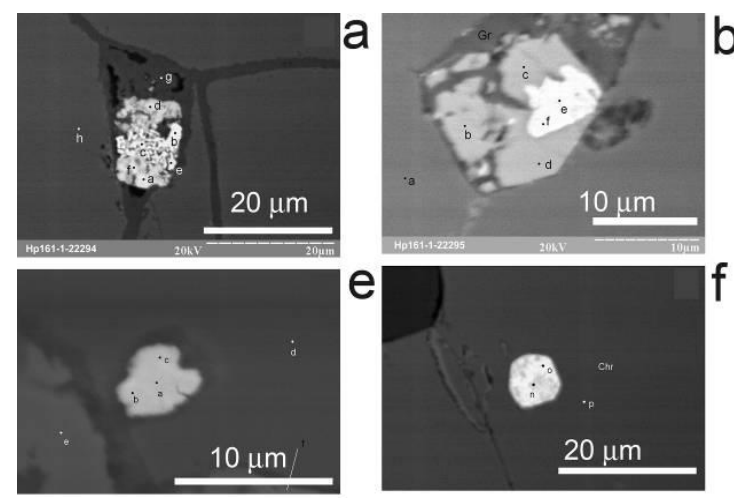
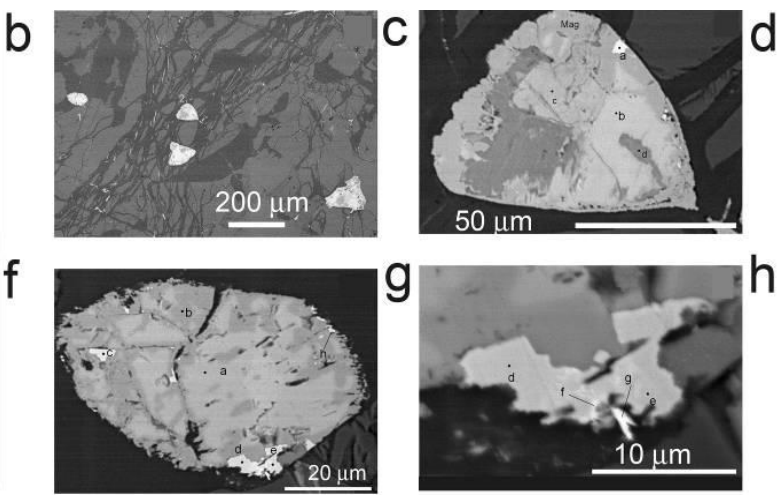

Fig. 17. Platinoids and sulfides from Zapadno-Sherambayskiy ore mineralization (Hp161)(Saveliev et al., 2017): $a$-native palladium Pt inclusion in Cr-spinel; $b$-crystals of pentlandite and cuprous Pt in $C r$-spinel; $e$-native palladium Pt inclusion in pyroxene; $f$-ferroplatinum crystal in Cr-spinel; $c, d$, $g, h$-accessory mineral inclusions in serpentinite; $d$-detailed photo $g$, awaruite inclusions associated with native Pt microinclusions

This is followed by the turfy area composed of serpentinites with different size gabbroid blocks. The one of them - outcrop $4 b$ (see Fig. 18) is situated south from Nurali Lake.
Near the ridge, at the elevation of $536.4 \mathrm{~m}$, Priozerny chromitite ore mineralization is located. It is hosted by wehrlites and pyroxenites (outcrop 4c, see Fig. 18). This mineralization was discovered by (Smirnov, 
Volchenko, 1992; Smirnov, 1995). In publications, different names are used: CHR-I (Zaccarini et al., 2004), and "South Miass" (Grieco et al., 2007).

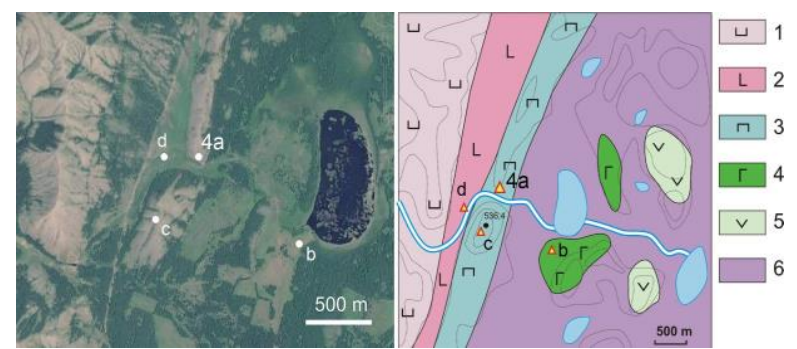

Fig. 18. The scheme of geological structure and location of outcrops $4(a-d): 1$ - spinel peridotites, 2 - dunites, 3 - wehrlite-clinopyroxenite complex, 4 - gabbroids, 5 - volcanogenic rocks, 6 - serpentinite mélange.4) The fractionally alternated wehrlites, olivine clinopyroxenites, horneblendites and melanocratic gneissous amphibole gabbroids. Significantly, hornblendite rocks frequently occur in ultramafites as conformed veins with thickness ranged from $1-2 \mathrm{~cm}$ to 2-3 $\mathrm{m}$. The thickness of the horizon is $50-70 \mathrm{~m}$

The ore mineralization is located at the Malyy Nurali Ridge with elevation of 536.4 $\mathrm{m}$ b.s.l. The ore mineralization is a lens- and schlieren-shaped ore body composed of coarse-grained thick impregnated chromitites hosted in wehrlite-pyroxenite rocks. Chromitites are confined to significantly serpentinized and rodingtized orthopyroxene rocks (Smirnov, 1995). The main lens is submeridionally elongated with $10 \times 3 \mathrm{~m}$ of size. There are several small chromitite bodies up to $1 \times 0.5 \mathrm{~m}$ in size. Furthermore, several more chromitite bodies hosted in clinopyroxenites, wehrlites and olivine-enstatite rocks at the adjacent area are described in literature (Grieco et al., 2007).

At the Priozerny ore mineralization, $\mathrm{Cr}$ spinels are widespread and geochemically similar to such in peridotites and middlechromous ores of the central part of the massif. The main component contents are (wt. \%): $\mathrm{Cr}_{2} \mathrm{O}_{3}$ 31-35, $\mathrm{Al}_{2} \mathrm{O}_{3}$ 34-38, $\mathrm{MgO}$ 14-16,
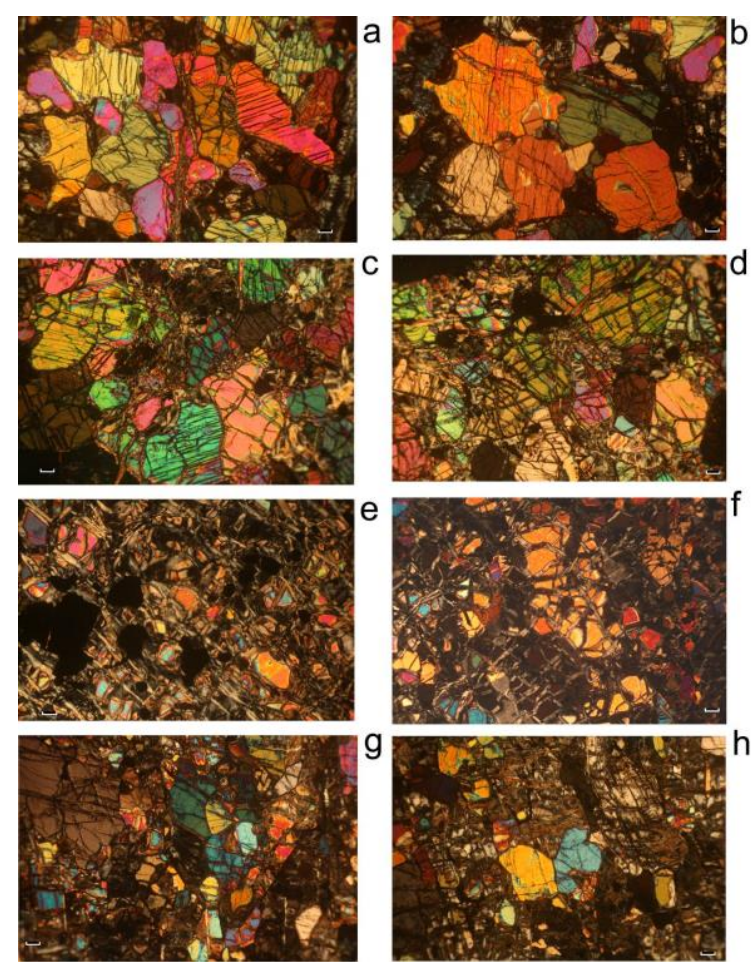

Fig. 19. Petrographical peculiarities of the transition zone rocks. Cross polarized translucent light. $a-b$-olivine clinopyroxenites, $c-d-w e h r-$ lites, $e-f-$ dunites of transition complex, $g-h-$ olivine websterites
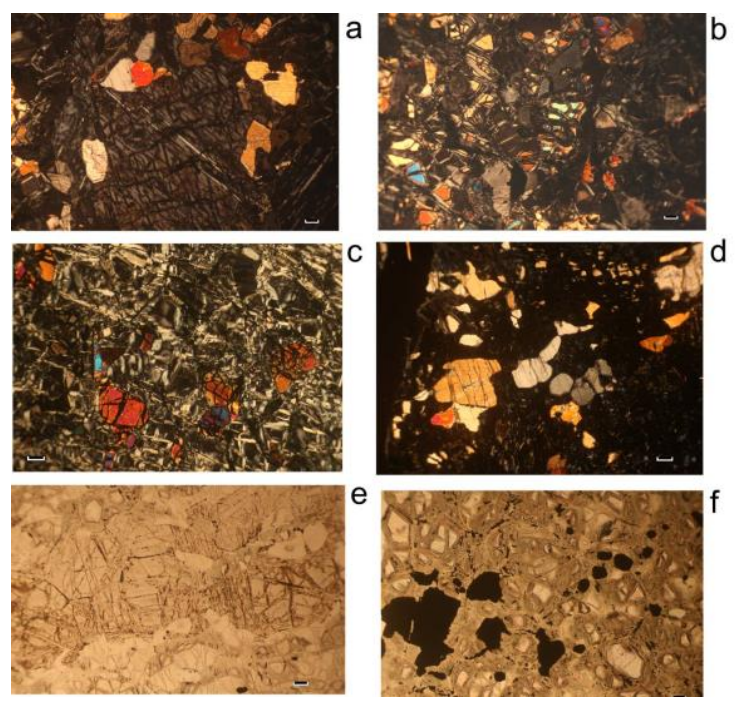

Fig. 20. Petrograhical peculiarities of rocks from the transition wehrlite-clinopyroxenite complex.Transmitted light. $a-d-$ crossed nicols, $e-f$ - parallel nicols, a-large orthopyroxene crystal with clinopyroxene inclusions (websterite), $b-$ serpentinized enstatite-olivine rock, $c$ - clinopyroxene in apoolivine groundmass (wehrlite), $d-$ 'fresh' clinopyroxene strias in apoolivine groundmass (wehrlite), $e$-bastite pseudomorphs and apoolivine looped (enstatite-olivine rock), $f-$ Cr-spinels in wehrlite 
$\mathrm{FeO}$ 14-17. Admixture elements are $\mathrm{MnO}$ (0.09-0.49) and $\mathrm{NiO}$ (up to $0.29 \%$ ). Cr spinels form euhedral and subhedral coarsegrained aggregates (1-10 $\mathrm{mm}$ in size).

The mineralized ultramafic rocks and chromitites of the Priozernyy ore mineralization contain PGE from 1.5-2.5 up to $26 \mathrm{ppm}$ (Zaccarini et al., 2004; Grieco et al., 2007; etc). PGM are Os-Ru and Ni-Fe-Ir-Ru-Os intermetallides, $\mathrm{Ru}$ and Os sulfides (lauriteerlichmanite), $\mathrm{Rh}$ pentlandite, and $\mathrm{Ru}-\mathrm{Os}-\mathrm{Ir}-$ Fe oxides (Moloshag, Smirnov, 1996; Zaccarini et al., 2004; Grieco et al., 2007; Saveliev et al., 2017) (Fig. 23).

\section{The origin of the ultramafic rocks of the Nurali massif}

The formation of rocks at the massif has been interpreted in different ways. Until the $1980^{\text {s }}$ the hypothesis about the magmatic formation of ultramafic rocks and gabbros had been prevailed (Rudnik, 1965; Shumikhin, 1980). After the investigation of G.N. Savelieva and E.A. Denisova (1983), the massif has been considered as the typical example of ophiolite assemblage with mantle lherzolite ultramafites in the basis. Currently, it is generally accepted that the modern structural setting of the Nurali massif is resulted from the multiple tectonic movements.
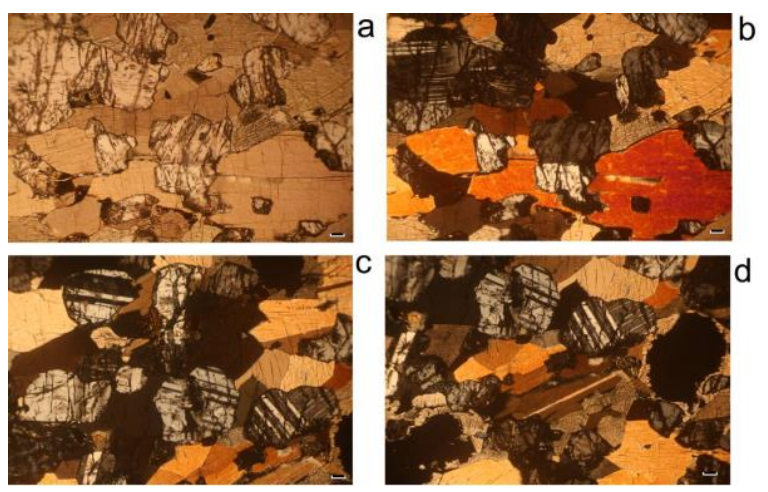

Fig. 21. Petrograhical peculiarities of gneissous hornblendite gabbro. Plate-polarized light. aparallel nicols, $b-d$-crossed nicols, $a-b-$ the same area; the main rock-forming minerals subhorizontal oriented prismatic hornblendite crystals, and twinned plagioclase

According to the model of G.N. Savelieva (1987), the peridotites of a mantle section are a weakly depleted upper mantle material ex- posed to a plastic flowing and metamorphic differentiation under a decompressive rise. At the later stages, the strain rate was increased sharply, and the partial melting became more intensive resulting in the melt separation and formation of strongly depleted dunite-harzburgite zone

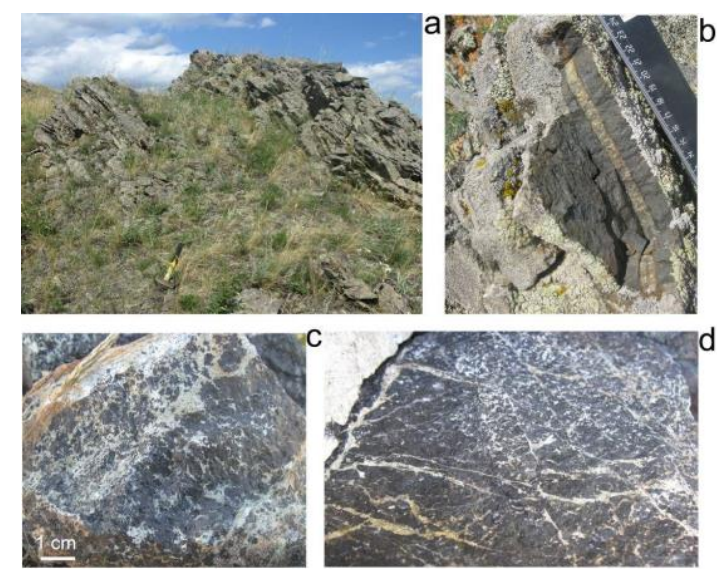

Fig. 22. Outcrops of wehrlite-clinopyroxenite ultramafic complex and chromitites of Priozernyy ore mineralization

The problems of the geodynamic setting and formation of the transitional wehrliteclinopyroxenite complex and gabbroids are particularly discussed. According to literature (Smirnov, 1995; Moloshag, Smirnov, 1996), the transition wehrlite-clinopyroxenite complex was formed due to an interaction between gabbroids and mantle ultramafic rocks. In publications (Pertsev, Savelieva, 1997; Savelieva, 1987), it is argued that the transition zone of Nurali massif was formed due to a multiple integration of melts derived from a progressive depleted mantle source during the spreading at $\mathrm{P}=6-8 \mathrm{kbar}$.

However, based on the REE and PGE geochemical study, Fershtater and Bea (1996), and Zaccarini et al. (2004) examined the differences between the ultramafites and gabbros of the transition zone and spreading environments. Particularly, amphibole gabbro and diorites are calc-alkali with elevated $\mathrm{K}$ and large-ionic lithophyle elements (LILE) comparing to oceanic tholeiites. It testifies that the Nurali massif is compatible with "orogenic lherzolites" of the subcontinental mantle of the Western Alps, Pyrenees and Betic Cordillera. 

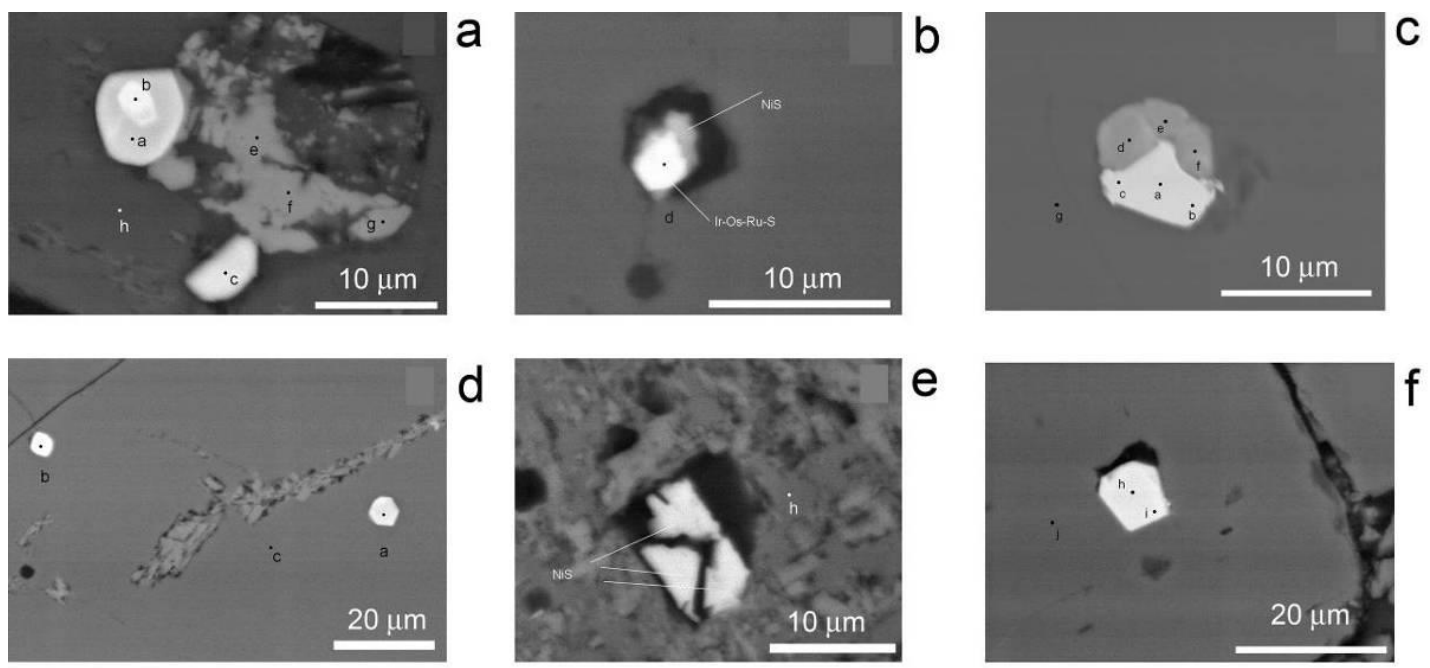

Fig. 23. The inclusions of platinoids and sulfides in chromitites of Priozernyy ore mineralization. After (Saveliev et al., 2017): $a-P G E$ sulfides and heaslewoodite intergrowth; $b-I r-O s-R u \_S$ and NiS mineral intergrowth in Cr-spinel; $c$-platinoid inclusions in Cr-spinelide; $d$-laurite inclusions in $\mathrm{Cr}$ spinel; $e$-millerite inclusions in Cr-spinel; $f$-laurite inclusions in Cr-spinel

The structural and geochemical data indicate the massif was formed within the undercontinental mantle, most likely within the rift structure (Chashchukhin et al., 2007; Saveliev et al., 2008). The structural and geochemical data of dunites from the Nurali massif (Denisova, 1990) and similar Kraka massif (Saveliev, Blinov, 2015) indicate a reomorphic origin of dunites and related $\mathrm{Cr}$ spinelides.

Acknowledgements. This work was performed as part of government contract of The Federal Agency for Scientific Organizations (FASO Russia), themes "The model of chrome ore deposits formation in ophiolites (20152017)», "Ore mineralization of the ultramafic and black shale complexes in the north part of Magnitogorsk megazone» (2018-2020), № 02522017-0014, 0246-2019-0078, and project of International conference "Magmatism of the Earth and related ore deposits (Miass, 4-9 august 2017»

\section{References}

Barnes S., Roeder P. 2001. The range of spinel compositions in terrestrial mafic and ultramafic rocks. Journal of Petrology. 42:22792302. doi: $10.1093 /$ petrology/42.12.2279

Carter N.L. 1976. Steady state flow of rocks. Rev. Geophys. and Space Phys. 14:301-360. doi: 10.1029/RG014i003p00301
Cassard D., Nicolas A., Rabinowitch M., Moutte J., Leblanc M., Prinzhoffer A. 1981. Structural Classification of Chromite Pods in Southern New Caledonia. Economic Geology, 76:805831. doi: 10.2113 /gsecongeo.76.4.805

Chashchukhin I.S., Votyakov S.L., Shchapova $Y u$.V. 2007. Kristallokhimiya khromshpineli i oksitermobarometriya ultramafitov skladchatykh oblastey [Crystal chemistry of chrome spinel and oxithermobarometry of ultramafites from fold belts]. IGG UB RAS, Ekaterinburg, p. 310. (in Russian).

Denisova E.A. 1990. Stroenie i deformatsionnye struktury ofiolitovykh massivov s lertsolitovym tipom razreza [Building and deformation textures of lherzolite-type ophiolite massifs]. Geotektonika. 2:14-27 (in Russian).

Dmitrenko G.G., Gorelova E.M., Savelieva G.N. 1992. Mineraly platinoidov v khromitakh massiva Nurali (Yuzhnyy Ural) [Platinum group minerals in chromites of the Nurali massif (the Southern Urals)]. Doklady Earth Sci. 324: 403-406. (in Russian)

Fershtater G.B., Bea F. 1996. Geokhimicheskaya tipizatsiya Uralskikh ofiolitov [Geochemical types of the Uralian ophiolites]. Geokhimiya. 3: 195-218. (in Russian)

Grieco G., Diella V., Chaplygina N.L., Savelieva G.N. 2007. Platinum group elements zoning and mineralogy of chromitites from the cumulate sequence of the Nurali massif (Southern Urals, Russia). Ore Geol. Reviews. 30:257276. doi: 10.1016/j.oregeorev.2006.03.002 
Kovalev S.G., Salikhov D.N. 2000. Poleznye iskopaemye Respubliki Bashkortostan (Khromitovye rudy) [Minerals of the Republic of Bashkortostan (Chromite ore)]. Ekologiya, Ufa, p. 207. (in Russian)

Kovalev S.G., Snachev V.I., Saveliev D.E. 1998. Poloschatye kompleksy giperbazitovykh massivov bashkirskogo Urala [The banded ultramafic complexes of the Bashkir Urals]. Preprint. IG USC RAS, Ufa, p. 24. (in Russian)

Malich K.N., Anikina E.V., Badanina I.Yu., Belousova E.A., Pushkarev E.V., Hiller V.V. 2016. Veshchestvennyy sostav i osmievaya izotopiya pervichnykh i vtorichnykh assotsiatsiy mineralov platinovoy gruppy magnezialnykh khromitov Nuralinskogo lertsolitovogo massiva (Yuzhnyy Ural, Rossiya) [The composition and Os isotopic data of the primary and secondary PGM of Mg chromitites of the Nurali lherzolite massif (South Urals, Russia)]. Geologiya rudnykh mestorozhdeniy. 58: 3-22. (in Russain)

Moloshag V.P., Smirnov S.V. 1996. Platinoidnaya mineralizatsiya Nuralinskogo giperbazitgabrovogo massiva (Yuzhnyy Ural) [PGE mineralization of the Nurali ultramaficgabbroic massif (the South Urals)]. Zapiski RMO. 1:48-54 (in Russian)

Pertsev A.N., Savelieva G.N. 1997. Rassloennaya dunit-klinopiroksenitovaya seriya $\mathrm{v}$ ofiolitakh massiva Nurali, Yuzhnyy Ural [Layered dunite-clinopyroxenite series in ophiolites of the Nurali massif, the South Urals]. Petrologiya. 5: 541-551 (in Russian)

Pertsev A.N., Spadea P., Savelieva G.N., Gaggero L. 1997. Nature of the transition zone in the Nurali ophiolite, southern Urals. Tectonophysics. 276:163-180

Poirier J.-P. 1985. Creep of crystals. Hightemperature deformation processes in metals, ceramics and minerals. London, Cambridge University Press, p. 287

Rudnik G.B. 1965. Petrogenezis ultraosnovnykh porod Nuralinskogo massiva na Yuzhnom Urale [Ultramafic rocks petrogenesis in the Nurali massif, the South Urals]. In Sootnoshenie magmatizma i metamorfizma $\mathrm{v}$ genezise ultrabazitov. Nauka, Moskva, pp. 68100. (in Russian)

Saveliev D.E., Blinov I.A. 2015. Sindeformatsionnye vydeleniya khrom-shpinelidov $\mathrm{v}$ plasticheski deformirovannykh agregatakh olivine (ofiolity Kraka, Yuzhnyy Ural) [Syndeformation chrome spinel exsolutions in the plastic deformed olivine aggregates (Kraka ophiolite, the Southern Urals)]. Vestrnik Permskogo universiteta. Geologiya. 4: 45-69 (in Russian) doi: 10.17072/psu.geol.29.44

Saveliev D.E., Zaykov V.V., Kotlyarov V.A., Zaykova E.V., Kraynev Yu.D. 2017. Khromshpinelidy i aktsessornaya mineralizatsiya $\mathrm{v}$ khromitakh i ultramafitakh Nuralinskogo massiva (Yuzhnyy Ural) [Chromespinelides and accessory mineralization in chromitites and Ultramafites of the Nurali massif, Southern Urals]. Zapiski RMO. 1:59-83. (in Russian)

Saveliev D.E., Snachev V.I., Savelieva E.N., Bazhin E.A. 2008. Geologiya, petrokhimiya i khromitonosnost gabbro-giperbazitovykh massivov Yuzhnogo Urala [Geology, petrogeochemistry and chromite-bearing gabbroultramafic massifs in the South Urals]. DizaynPoligrafServis, Ufa, p. 320. (in Russian)

Savelieva G.N. 1987. Gabbro-ultrabazitovye kompleksy ofiolitov Urala i ikh analogy v sovremennoy okeanicheskoy kore [Gabbroultrabasitic complexes of the Urals ophiolites and their analogues in the present-day oceanic crust]. Nauka. Moskva, p. 230 (in Russian)

Savelieva G.N., Denisova E.A. 1983. Struktura i petrologiya ultraosnovnogo massiva Nurali na Yuzhnom Urale [Structure and petrology of Nurali ultramafic massif in the South Urals]. Geotektonika. 2:42-57 (in Russian)

Smirnov S.V. 1995. Petrologiya verlit-klinopiroksenit-gabbrovoy assotsiatsii Nuralinskogo giperbazitovogo massiva i svyazannoye s nim platinoidnoe orudenenie [Petrology of the wehrlite-clinopyroxenite-gabbro association of the Nurali ultrabasite massif and associated PGE mineralization]. Thesis cand.geol.min.nauk. IGG UB RAS. Ekaterinburg. (in Russian)

Smirnov S.V., Volchenko Yu.A. 1992. Pervaya Nakhodka platinoidnoy mineralizatsii $\mathrm{v}$ khromitovykh rudakh Nuralinskogo massiva na Yuzhnom Urale [First finding of PGE mineralization in chromite ores of Nuraly massif in the South Urals]. In Ezhegodnik 91. IGG UB RAS, Ekaterinburg, pp. 115-117 (in Russian)

Zaccarini F., Pushkarev E.V., Fershtater G.B., Garuti G. 2004. Composition and mineralogy of PGE-rich chromitites in the Nurali lherzolite-gabbro complex. Can. Miner. 42:545562. doi: 10.2113/gscanmin.42.2.545 
Znamenskiy S.E., Danilenko S.A., Kovalev S.G., Snachev V.I. 1996. Geneticheskie tipy i platinonosnost khromitov Nuralinskogo gabbrogiperbazitovogo massiva (Yuzhnyy Ural) [Genetic types and platinum potential of $\mathrm{Nu}$ - rali gabbro-ultramafic massif chromites (the South Urals)]. In Poznanie, osvoenie i sberezhenie nedr Respubliki Bashkortostan, Ufa, pp. 33-34. (in Russian)

\title{
Нуралинский офиолитовый массив
} (Южный Урал: геологические, структурные и минералогические особенности)

\author{
Д.Е. Савельев ${ }^{a}$, Н.Н. Анкушева ${ }^{b}$

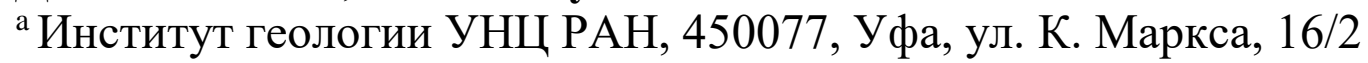 \\ E-mail: sav171@mail.ru \\ ${ }^{\mathrm{b}}$ Южно-Уральский государственный университет, Миасский филиал, \\ 456300, Челябинская область, Миасс. E-mail: ankusheva@ mail.ru
}

\begin{abstract}
Проведен обзор геологического строения Нуралинского массива. Приведены данные о составе пород мантийного разреза и переходной мантийно-коровой ассоциации, акцессорных и рудообразующих хромшпинелидов. Ультрамафиты мантийной последовательности (шпинелевые и шпинель-плагиоклазовые перидотиты, гарцбургиты и дуниты) являются тектонитами. Они показывают сильную предпочтительную оптическую ориентировку породообразующего оливина, обусловленную пластическим течением пород. Приведены различные точки зрения на генезис переходной мантийно-коровой ассоциации, сложенной верлитами, клинопироксенитами, вебстеритами, дунитами и меланократовым гнейсовидным габбро. Описаны проявления хромит-платиноидной минерализации в этой части офиолитового разреза. Данная статья подготовлена на основе путеводителя международной экскурсии на Нуралинский массив, проведенной в рамках конференции «Магматизм Земли и связанные с ним месторождения стратегических металлов».

Ключевые слова: офиолиты, ультрамафиты, хромшпинелиды, платиноиды, Южный Урал, Нурали.
\end{abstract}

\section{Библиографический список}

Barnes S., Roeder P. The Range of spinel compositions in terrestrial mafic and ultramafic rocks // Journal of Petrology. 2001. Vol. 42. P. 2279-2302.

Carter N.L. Steady state flow of rocks // Rev. Geophys. and Space Phys. 1976. Vol. 14. P. 301-360.

Cassard D., Nicolas A., Rabinowitch M., Moutte J., Leblanc M., Prinzhoffer A. Structural Classification of Chromite Pods in Southern New Caledonia // Economic Geology. 1981. Vol. 76. P. 805-831.

Grieco G., Diella V., Chaplygina N.L., Savelieva G.N. Platinum group elements zoning and mineralogy of chromitites from the cumulate sequence of the Nurali massif (Southern
Urals, Russia) // Ore Geol. Reviews. 2007. Vol. 30. P. 257- 276.

Pertsev A.N., Spadea P., Savelieva G.N., Gaggero $L$. Nature of the transition zone in the Nurali ophiolite, southern Urals // Tectonophys. 1997. Vol. 276. P. 163-180.

Poirier J.-P. Creep of crystals. High-temperature deformation processes in metals, ceramics and minerals. London, Cambridge University Press, $1985.287 \mathrm{p}$.

Zaccarini F., Pushkarev E.V., Fershtater G.B., Garuti $G$. Composition and mineralogy of PGE-rich chromitites in the Nurali Lherzolite-gabbro complex // Can. Miner. 2004. Vol. 42. P. 545-562.

Денисова Е.A. Строение и деформационные структуры офиолитовых массивов с лерцолитовым типом разреза // Геотектоника. 1990. № 2. C. 14-27. 
Дмитренко Г.Г., Горелова Е.М., Савельева Г.Н. Минералы платиноидов в хромитах массива Нурали (Южный Урал) // Докл. PAH. 1992. Т. 324, № 2. C. 403-406.

Знаменский С.Е., Даниленко С.А., Ковалев С.Г., Сначёв В.И. Генетические типы и платиноносность хромитов Нуралинского габбро-гипербазитового массива (Южный Урал) // Познание, освоение и сбережение недр Республики Башкортостан. Уфа, 1996. С. 33-34.

Ковалев С.Г., Салихов Д.Н. Полезные ископаемые Республики Башкортостан (Хромитовые руды). Уфа: Экология, 2000. 207 с.

Ковалев С.Г., Сначев В.И., Савельев Д.Е. Полосчатые комплексы гипербазитовых массивов Башкирского Урала: препринт / ИГ УНЦ РАН. Уфа, 1998. 24 с.

Малич К.Н., Аникина Е.В., Баданина И.Ю., Белоусова Е.А., Пушкарев Е.В., Хиллер В.В. Вещественный состав и осмиевая изотопия первичных и вторичных ассоциаций минералов платиновой группы магнезиальных хромититов Нуралинского лерцолитового массива (Ю.Урал, Россия) // Геология рудных месторождений. 2016. T. 58, №1. С. 3-22.

Молошаг В.П., Смирнов С.В. Платиноидная минерализация Нуралинского гипербазитгаббрового массива (Южный Урал) // Записки РМО. 1996. №.1. С. 48-54.

Периев А.Н. Савельева Г.Н. Расслоенная дунит-клинопироксенитовая серия в офиолитах массива Нурали, Южный Урал // Петрология. 1997. № 5. С. 541-551.

Рудник Г.Б. Петрогенезис ультраосновных пород Нуралинского массива на Южном Урале // Соотношение магматизма и метаморфизма в генезисе ультрабазитов. М.: Наука, 1965. С. 68-100.

Савельев Д.Е., Блинов И.А. Синдеформационные выделения хромшпинелидов в пласти- чески деформированных агрегатах оливина (офиолиты Крака, Южный Урал) // Вестник Пермского университета. Геология. 2015. № 4. C. 44-69.

Савельев Д.Е., Зайков В.В., Котляров В.А., Зайкова Е.В., Крайнев Ю.Д. Хромшпинелиды и акцессорная минерализация в хромититах и ультрамафитах Нуралинского массива (Южный Урал) // Записки РМО. 2017. № 1. C. 59-83.

Савельев Д.Е., Сначёв В.И., Савельева Е.Н., Бажин E.A. Геология, петрогеохимия и хромитоносность габбро-гипербазитовых массивов Южного Урала. Уфа: ДизайнПолиграфСервис, 2008. 320 с.

Савельева Г.Н. Габбро-ультрабазитовые комплексы офиолитов Урала и их аналоги в современной океанической коре. М.: Наука, 1987. 230 с.

Савельева Г.Н., Денисова Е.А. Структура и петрология ультраосновного массива Нурали на Южном Урале // Геотектоника. 1983. № 2. C.42-57.

Смирнов С.В. Петрология верлит-клинопироксенит-габбровой ассоциации Нуралинского гипербазитового массива и связанное с ним платиноидное оруденение: автореф. дис. ... канд. геол.-мин.наук. Екатеринбург, $1995.18 \mathrm{c}$.

Смирнов С.В., Волченко Ю.А. Первая находка платиноидной минерализации в хромитовых рудах Нуралинского массива на Южном Урале // Ежегодник - 91 / ИГиГ УрО РАН. Екатеринбург, 1992. С. 115-117.

Феритатер Г.Б., Беа Ф. Геохимическая типизация уральских офиолитов // Геохимия. 1996. №3. С. 195-218.

Чамухин И.С., Вотяков С.Л., Щапова Ю.В. Кристаллохимия хромшпинели и окситермобарометрия ультрамафитов складчатых областей / ИГиГ УрО РАН. Екатеринбург, 2007. 310 c. 